\title{
APPROACHES TO LEARNING THROUGH GROUP WORK: AN EMPIRICAL ANALYSIS OF STUDENT PERCEPTIONS
}

\author{
Margaret Healy, Maeve McCutcheon and John Doran \\ University College Cork
}

\begin{abstract}
Croup work is used to promote employability and deeper learning in $\checkmark$ accounting education. Prior research examines outcomes but there is little understanding of actual group work processes. This exploratory study revisits, builds on and expands the work of Tempone and Martin (1999), who focused on approaches to learning in a group setting and their impact on the group work process. This study is distinguished by its emphasis on students' cumulative experiences of group work over the entirety of a programme of undergraduate study. It reports that those indicating deep approaches to learning in a group work context attach higher value to their experience, appearing more engaged. However, those indicating strategic approaches differ little from those indicating surface approaches but find the experience more challenging, completing the task without underlying belief in either the value or relevance of group work activities. In order to address students' approach to learning, it is necessary to first address their motivation and then persuade them of the relevance of group work to accounting education. This requires a coordinated and consistent approach, involving dialogue both between lecturers within a programme and more importantly between lectures and students.
\end{abstract}

Keywords: group work; student perceptions; approaches to learning 
Healy et al.

\section{INTRODUCTION}

From accounting's inception as a professional discipline, it has been argued that accounting education should be viewed as a means of preparing students to become accountants rather than simply to be accountants (Previts and Merino, 1997; Wyhe, 2007). When considering accounting education in its broadest sense, it is argued a liberal education should be intertwined with a practical vocational education to develop the professional accountant (Merino, 2006; Wilson, 2011). However despite these early ambitions, the pedagogy in accounting typically emphasises rote-based learning and technical skills (Hopper, 2013). Typically in a tertiary setting, students are passive recipients of the techniques of accounting practice through didactic lectures in large class settings (Bunniss, 2006). Calls for change in accounting education have involved both a recognition of the failure of accounting education to live up to the early ideals of professional education and a practical recognition that accounting education as delivered is failing to prepare accountants for the changing nature of their role(s) in the twenty-first century (Evans, Burritt and Guthrie, 2012; Wyatt, 2004).

Arguably, the most comprehensive and cited change initiative has been the work of the Accounting Education Change Commission (AECC, 1990) which sought both curricular change with a shift in emphasis to a broader curriculum including the liberal arts, and pedagogic change with a move away from textbook, rule-based teaching to a case-based approach incorporating active and team teaching. The AECC vision was not broadly supported by faculty and a decade later, Albrecht and Sack (2000) reported that as the pace of change in the business environment intensified, accounting education had fallen further behind. All the earlier problems of a narrow curriculum, outmoded pedagogy, lack of skills development and an isolated faculty remained (Albrecht and Sack, 2000). Of course, the failure to adopt the AECC vision could well reflect the espousal of an alternative perspective on accounting education, which places greater emphasis on education as the development of individual capabilities rather than the needs of the profession (Brown and McCartney, 1995).

Group work is one strategy used to achieve pedagogic change in accounting education. As a model for enhancing graduate and undergraduate education, proponents argue for its use in the development of soft skills, as well as positing its impact on the quality of the learning experience through encouragement of a deeper approach to learning (in the Irish context specifically, see Quality and Qualifications Ireland, 2014). However, as the literature on approaches to learning in accounting education suggests, a change in the learning tasks may encourage a change in the student approach to learning, but this requires students to be motivated and engaged with the new approach (Lucas and Mladenovic, 2004). A shift from the comfort of well-defined and already mastered methods of teaching entails significant costs and risks (Bui and Porter, 2010; Roslender, 2002). Students may well be resistant to techniques which seek to encourage them to question what is assumed. Innovators seeking to challenge students may find that their engagement is partial or temporary (Chabrak and Craig, 2013). 
Tempone and Martin (1999) contend that if students can perceive little value in tackling assignments and learning in groups, then successful experiences are unlikely to follow. The manner in which group work is implemented by lecturers and approached by students may be central to the skills and benefits reported. The reality of group work in accounting education is that it frequently falls short of the ideals of cooperative learning. However, as Healy, Doran and McCutcheon (2018) report, even attempts at introducing group work in less than ideal conditions can result in significant perceived benefits for the students. The literature also suggests that early experiences of group work will influence attitudes to, and benefits derived from, group work in subsequent modules (Hillyard, Gillespie and Littig, 2010).

Much of the prior research work is focused on single instances of assessed group work, with unintended outcomes not always recognised or captured. Little attention has been focused on the process of group work and the extent to which students are motivated to adopt deep learning approaches. It is unclear whether their engagement with group work encompasses not alone achieving valuable skills or high grades but also deeper transformative learning experiences. This study is important for a number of reasons. It adds to the literature by considering how students' experiences of working in groups, based on holistic recollection of the duration of a four-year programme of study, indicate particular approaches to learning. In contrast with prior studies, the research setting did not dictate the research question, in terms of a specific group-based intervention. The programmatic emphasis reflects the natural period of undergraduate education in relation to which individuals reflect upon and recognise the skills they deem themselves as having acquired. Secondly, in its findings section, associations between group work and approaches to learning posited in the prior research (Tempone and Martin, 1999) are now related to levels of engagement and the perceived value of group work. This provides greater insight for educators seeking to optimise the alignment of such experiences with programme learning outcomes.

The remainder of the paper is organised as follows. First, the literature review considers two prior research strands: approaches to learning in accounting education and accounting students' experiences of group work. Second, the research approach used in this study is presented and described. Third, the research findings document the approaches taken by accounting students to learning through group work. These approaches are then related to the student perspectives on their experiences of group work, and their perceptions of the value they derived from those experiences. Finally, the implications of the findings are considered and discussed.

\section{LITERATURE REVIEW}

If accounting education is to become fit for purpose, it requires both change to what is taught but also pedagogic change with the restructuring of traditional classroom time (Schultz, 1989). Group work as a pedagogic strategy has its antecedents in cooperative learning. Cooperative learning, as defined by Johnson and Johnson (1999, p. 73), is 'the instructional use of small groups in which students work 
Healy et al.

together to maximise their own and each other's learning'. Proponents of cooperative learning in the university setting claim that it can deliver critical skills such as teamwork, communication and negotiation, while simultaneously enhancing the motivation of students and encouraging deeper learning with an improved understanding of the underlying curriculum. From this perspective, the development of cooperative learning should be central to the enhancement of undergraduate accounting education.

Group work is not synonymous with cooperative learning. The potential benefits of cooperative learning are well documented, as are the difficulties in achieving true cooperative learning through the use of group assignments (Norman, Rose and Lehmann, 2004). While ideally group work provides the type of active learning experience that cooperative learning envisages and leads to higher-order learning outcomes, it can also result in conflict, dysfunctional behaviours such as storming and free-rider issues, and under-performance (Gammie and Matson, 2007; Davies, 2009). Ravenscroft (1997) points out that, while there are gaps in our understanding and weaknesses in the existing research, the balance of evidence in accounting education shows positive achievement and attitudinal gains from students working with other students in groups and thus the benefits outweigh the costs. It can prove difficult to establish the extent to which cooperative learning as initially envisaged by Johnson and Johnson (1999) is taking place; instead attention needs to be directed to the approaches to learning in a group work setting.

The manner in which group work is implemented by lecturers and approached by students may be central to the skills and benefits reported. Much of the existing research on the benefits of group work focuses on the output of this group work. In particular, it considers the perceived value of group work in terms of skills and knowledge and the learning outcomes achieved. However, innovative pedagogy can only achieve improvement in the quality of the learning experience if it encourages approaches to learning which are constructively aligned with the outcomes sought. Where students adopt a surface approach, for example, being only concerned with grades, then higher quality outcomes will not be achieved. The key question therefore is whether group work can inspire deeper approaches to learning as envisaged in the cooperative learning literature.

The approaches to learning literature identifies a hierarchy of learning approaches by students in higher education. This literature is linked to the seminal work of Marton and Säljö (1976) on approaches to learning (further developed in Marton and Booth, 1997), which focused particularly on learning as neither cognitive nor behavioural but experiential (Byrne, Flood and Willis, 2002). The approaches have been categorised along a continuum which ranges from a superficial approach typified by a concern with knowledge acquisition, rote-learning and memorisation, to a deep approach that views learning as a quest for understanding which may ultimately be transformative. A third approach involves a motive for learning which is 'achieving' or 'strategic'; in the pursuit of high grades students may adopt either a surface or a deep approach (Ramsden, 2003). The importance of approaches to learning is that theoretically the quality of learning (as opposed to the quantity of learning) is affected by the students' approach to learning. 
An approach to learning is not posited to be a fixed individual characteristic but is instead influenced by the learning context. All students do not react in the same way to a common context; they each bring their own individual motivations to bear, but the strategy they adopt will reflect their perception of the learning task. Much of the accounting education literature in the context of learning approaches adapts the Biggs 3P model of Presage, Process and Product (Biggs and Tang, 2003). Presage relates to the background or context factors; Process is the learning activity itself; and Product refers to the learning outcome. From this perspective the approach to learning adopted by students can be changed and higher quality learning outcomes can be achieved if the learning process aligns constructively with students' own motivations.

The accounting education literature also suggests that accounting students are more likely than other students to be surface learners and this tendency is strengthened over time by their educational experiences (Kember and Gow, 1994). Accounting education, in its design and structure, can struggle to achieve balance between the vocational and liberal aspects of learning - more so than in other professions (Paisey and Paisey, 2000). Accounting students are also characterised as strategic learners and therefore may adapt to learning activities which encourage deeper learning where the assessment of those activities itself promotes deeper learning (Byrne and Flood, 2004). A problem encountered in the literature in linking approaches to learning and learning outcomes is that while in theory deeper approaches to learning should be related to higher-quality learning outcomes the measurement of the quality of learning outcomes is itself quite problematic. Successful students may be more likely to adapt surface learning strategies if prompted by the nature of assessment (Duff, 2004). In other words, the inclusion of learning activities which are intended to promote deeper learning may fail to achieve these objectives because the students who obtain the best grades from the assessment of these activities do so through a strategy which prioritises surface learning. A further problem inhibiting alignment between assessment and student learning approaches is the difficulty for students in engaging with the learning activities in a situation where personal motivation, ability and learning strategy are not congruent. The potential for dissonance between students' personal motivation(s) and their need to adopt a deeper learning strategy in order to achieve better grades may arguably be exacerbated by the adoption of novel or non-traditional learning activities which strategic, achieving students engage with reluctantly (Lucas and Mladenovic, 2004).

Tempone and Martin (1999) explore the question of how students approach an accounting task when working in a group. They use a phenomenographic analysis of interview data gathered from 35 students shortly after completing an assignment for a financial accounting module where there was an expectation they would work in groups. They contend that if students can see no real point in tackling assignments and learning in groups, then successful experiences are unlikely to follow. A range of approaches to group work, varying from a view of group work as a mechanism for subdividing tasks, to a view of group work as means of advancing collective knowledge, are identified. Tempone and Martin (1999) draw parallels between categorisations of group work and the surface and deep approaches to learning articulated by Marton and Säljö (1984). The surface approach is represented where 
Healy et al.

students view group work as something to be done or completed. A deep approach is evident where students perceive group work as a means of increasing individual and collective knowledge. Six approaches to group work emerged from the findings, reflecting a hierarchical outcome space (see Tempone and Martin, 1999, Table 1, p. 181), ranging from there being no advantage to working in groups (Category A), through to it being a mechanism for extending knowledge in general (Category F). Apart from Category A, all the categories of description depict positive aspects of group work, but convey variations in how group work was enacted in practice (See Appendix I).

Whilst offering a useful snapshot of students' approaches, the Tempone and Martin (1999) study also has a number of limitations. It is reasonable to assume that the specifics of the group work task underpinning the study - use of formal study groups, in association with an individual assignment submission - will have influenced student actions. If approaches to learning are not stable, and students are capable of being strategic, then perceptions of the assignment, rather than perceptions of group work per se, may be the dominant driver of the outcome space mapped. Indeed, Tempone and Martin (1999, p. 180) themselves state: 'The aim was to find out what students believed they had to know and to do in order to complete the assignment, and how they saw this relating to working in groups'. In other words, in their study, the framing of the assignment, including any specific instructions in relation to group work provided by the module lecturers (who were not the researchers), is likely to have strongly influenced the research findings subsequently reported and merits further investigation.

Cadiz Dyball, Reid, Ross and Schoch (2010) explore conceptions of group work in the context of a specific group-based assignment, using a sample of 362 second-year management accounting students at a large metropolitan Australian university. They used a phenomenographic method to analyse the conceptions of learning revealed by the students' responses to what they liked best and least about working in groups. They found that the majority of students (69 per cent of their sample) appeared to focus on aspects of group work which revealed elements of a deep approach to learning, such as breadth of vision, constructive relationships and applying theory in reality. However, this study did not explicitly address how students went about working in groups and the relationship between the approach to group work on the ground and the value of group work.

In summary, there is mixed evidence in relation to the benefits of group work in accounting education, with much of that work grounded in investigations of specific instances of group work interventions formed around the achievement of particular skills or competences desired by researchers. While these interventions are evaluated against attainment of higher-order learning outcomes, little investigation of the group work process, in terms of underlying approaches to learning, has been considered. Healy et al. (2018) investigated student perceptions of their cumulative experiences of group work at the end of a four-year undergraduate programme considering how gender and self-reported academic ability impact on those experiences. Their study combined a number of aspects of group work previously explored separately: group formation; perception of skills enhancement; experiences of group work; perceptions of the value of group work; and responses 
to the assessment of group work. Using an adaptation of the framework developed by Tempone and Martin (1999), this study extends the work of Healy et al. (2018) by specifically considering how students approach group work. It then relates those approaches to students' perceptions of their experiences and the value they gained from group work. The research objective of this study therefore is to explore the relationship between accounting students' perceptions of group work experiences and approaches to learning.

\section{RESEARCH CONTEXT}

The research findings of this study report the perceptions of students nearing the end of the fourth and final year of two honours (level 8) degree programmes in Accounting and Finance at one Irish university. A range of group activities had been experienced by the research sample over years 2, 3 and 4 of their respective undergraduate programmes. On these programmes the majority of students planned to subsequently undertake professional accounting qualifications. The programmes therefore of necessity included a number of modules which were structured to gain exemptions from professional body examinations. These modules typically did not offer scope for group work. However, given the length of the programmes there were a range of modules, in accounting and cognate disciplines, available to students (some compulsory, some optional) which did include group work. The researchers were happy that each student experienced a largely similar set of group work opportunities. The programmes did not include formal training in group work, although this may have happened at the level of individual modules (outside the research scope of this paper). These are summarised in Table 1. As the focus of this study is on the students' cumulative approach to group work, specific details of each individual instance of group work activity are not reported here.

TABLE I: GROUP WORK ACTIVITY, BYYEAR OF PROGRAMME

\begin{tabular}{lcc}
\hline $\begin{array}{c}\text { Year of } \\
\text { Programme }\end{array}$ & $\begin{array}{c}\text { \% of Modules with } \\
\text { Group Work }\end{array}$ & $\begin{array}{c}\text { \% of Year Marks Awarded } \\
\text { for Group Work }\end{array}$ \\
\hline Year I & - & - \\
Year 2 & $33 \%$ & $5 \%$ \\
Year 3 & $80 \%$ & $30 \%$ \\
Year 4 & Up to 50\% & Up to 10\% \\
\hline
\end{tabular}

Group activities undertaken by the research sample included case-based learning in finance and in management accounting modules, assessed group projects across a range of disciplines, and group exercises (not assessed) for an information systems module. Group size varied from groups of three students in year 2, to groups of up to four or five students in years 3 and 4 . In some instances, students were free to select their groups, whereas for others the groups were randomly assigned by the module lecturer. There was no evidence of a programmatic policy on group work, with the research sample instead exposed to a variety of approaches to the design, 
Healy et al.

implementation and assessment of group-based activity. In both programmes the individual module coordinators had autonomy to determine the nature of the continuous assessment. Programme boards essentially had a coordinating rather than a managerial function in this respect. The research population was homogenous as to age, ethnicity and general educational background prior to higher education.

\section{RESEARCH METHODOLOGY}

The findings of this study are based on data gathered using a survey methodology. The research instrument contained a mix of closed-end and open-ended questions, drawn directly from existing research instruments used in connected studies, both in Ireland and internationally (Ballantine and McCourt Larres, 2007; Bourner, Hughes and Bourner, 2001; Healy et al., 2018; Mills, 2003). Questions exploring the approaches to group work were designed based on the prior work of Tempone and Martin (1999). Using their descriptions of outcome spaces B through to F, questions relating to experiences of group work were derived based on the categories of description underpinning the work of Tempone and Martin (1999) (see Appendix 1). Students were asked to consider these in relation to their cumulative experiences of group work throughout the entirety of their four-year programme of study. Measured using Likert scales, the mean responses were calculated and are reported in the research findings.

Questions concerning the value of group work were informed by Panel A, Table 2 (group dynamics section) of Ballantine and McCourt Larres (2007). Questions concerning the experience of group work were drawn from Bourner et al. (2001) and have been used in other studies of group work (Healy et al., 2018; Mills, 2003), with samples drawn across a range of disciplines and years of study. For example, Bourner et al. (2001) surveyed first-year students taking an organisation behaviour module at an English university; Mills (2003) used a sample drawn from second-year undergraduate veterinary students in Australia; and Healy et al. (2018) surveyed final-year Accounting and final-year Finance degree students at one third-level institute in Ireland. Open-ended questions invited respondents to describe various aspects of group work, positive and negative, which impacted on their overall experiences of the group work process. These were considered to further illuminate the approaches to learning derived through the closed-end questions.

Respondents were asked to reflect upon and complete the survey instrument in light of the totality of their experiences of group work, assessed and otherwise, throughout their undergraduate studies. The survey instrument was administered during the penultimate week of the final year of the students' degree programmes. Completed anonymously, all students received the survey instrument at the same point in their studies, during a scheduled class for a module core to all programmes comprising the research sample. As the researchers had previously taught the students (in prior years), the survey was administered by a lecturer not involved in the research project. The researchers had no current involvement with the students in the research sample at the time the study was undertaken. All students present in class on that date completed the survey, generating a response rate of 76 per cent ( 84 of 110 students registered). Demographic details are presented in Table 2. 
Approaches to Learning Through Group Work

TABLE 2: DEMOGRAPHIC DETAILS

\begin{tabular}{lccc}
\hline & Sample Size & No. of Responses & \% Response Rate \\
\hline Male & 70 & 50 & $71 \%$ \\
Female & 40 & 34 & $85 \%$ \\
Total & 110 & 84 & $76 \%$ \\
\hline
\end{tabular}

Responses to the closed questions were analysed using a combination of MannWhitney $U$ tests and Kruskal-Wallis tests to establish statistical differences. The findings of the statistical analysis are also supplemented with data from openended questions describing what students felt were the best and worst aspects of working in groups, allowing the researchers to explore in greater depth aspects of their group work experiences considered salient by the research sample.

\section{RESEARCH FINDINGS}

Students were asked the extent of the agreement of their experience of group work with categories of description of the approach to group work identified by Tempone and Martin (1999) and expressed in terms of the five statements listed in the first column of Table 3. However, students were asked to consider these based on reflection of their cumulative group work experiences to date, rather than in relation to any specific single group assessment task. This focus on cumulative experience rather than most frequent or most recent experience is informed by evidence in the literature of the potential importance of past negative or positive experiences on subsequent perceptions of experience (Hillyard et al., 2010). In so doing, the researchers sought to address concerns raised by Pauli, Mohiyeddini, Bray, Michie and Street (2008) regarding the extent to which negative myths of group work become perpetuated on the basis of evidence collected from a more narrowly defined instance of the student experience of group work (for example, on the basis of a single piece of assessed group work).

TABLE 3: GROUP WORK PROCESS

\begin{tabular}{|c|c|c|c|}
\hline $\begin{array}{c}\text { Group Work Process } \\
\text { (Scale: } 5 \text { = Strongly agree; } I \text { = Strongly disagree) }\end{array}$ & $\begin{array}{c}\text { All } \\
\text { Mean (SD) }\end{array}$ & Male & Female \\
\hline $\begin{array}{l}\text { Statement I: Each individual did one part of the } \\
\text { assignment. }\end{array}$ & 3.31 (0.96) & 3.30 & 3.35 \\
\hline $\begin{array}{l}\text { Statement 2: Sections prepared by individuals were } \\
\text { discussed and refined by the group as a whole. }\end{array}$ & $3.63(1.04)$ & 3.70 & 3.59 \\
\hline $\begin{array}{l}\text { Statement 3:The group shared ideas on all sections of the } \\
\text { assignment. }\end{array}$ & $3.62(1.08)$ & 3.47 & 3.88 \\
\hline $\begin{array}{l}\text { Statement } 4: \text { The group discussed the underlying concepts } \\
\text { of the assignment and helped individual group members } \\
\text { gain a better understanding. }\end{array}$ & $3.54(1.03)$ & 3.55 & 3.53 \\
\hline $\begin{array}{l}\text { Statement 5:The group as a whole gained a deeper } \\
\text { understanding of the subject areas. }\end{array}$ & $3.67(0.77)$ & 3.72 & 3.56 \\
\hline
\end{tabular}


Healy et al.

The combination of each student response (across all five statements) was then used to place that student into a hierarchy of approaches to group work, moving from a surface approach focused on the accomplishment of particular group tasks, to deeper levels of collaborative learning, as shown in Table 4 (see Appendix 1 for specific details of this analysis). Seventeen inconsistent responses regarding the group work process were identified. The inconsistent responses may be a reflection of inconsistent experiences and a necessary result of this study's focus on cumulative experiences. These were excluded from further analysis, given the focus of this study on group work processes and students' approaches to learning. These students agreed with statements concerning higher levels of learning (reflecting deeper engagement), but were missing positive responses to lower levels of the hierarchy. In total, for 37 per cent of students (31 of the remaining 67 respondents) a deep approach to learning via group processes (as defined by Tempone and Martin, 1999 ) is reported while for 43 per cent (36 of the remaining 67 respondents) a surface approach is identified. The research sample is also sub-divided based on gender and there were no significant differences.

Tempone and Martin (1999) use a dichotomous approach to the categorisation of approaches to learning and do not allow for a strategic approach, where students apply a mix of surface and deep approaches. Having revisited their categorisation in the context of the literature on strategic approaches, and having reviewed the students' responses to the open-ended questions, it is apparent that those students in categories C, D and E (Tempone and Martin, 1999) would better be described as reflecting a strategic (achieving) (designated SA in Table 5) rather than a deep or surface approach. In all cases, the students go beyond the bare bones of the tasks set and use group work as a means of enhancing the output from its process. However, they do not move outside the boundaries of the assignment in a manner which would be consistent with deeper learning. It also appears that they are concerned to achieve as high a grade as possible, as efficiently as possible. Table 5 presents the group work approaches, re-categorised on this basis.

TABLE 4: GROUP WORK APPROACHES, ASSOCIATED WITH APPROACHES TO LEARNING

\begin{tabular}{|c|c|c|c|c|c|c|c|}
\hline $\begin{array}{l}\text { Learning } \\
\text { Approach }\end{array}$ & Group Work Process & $\begin{array}{l}\text { Total } \\
\text { No. }\end{array}$ & $\%$ & $\begin{array}{l}\text { Male } \\
\text { No. }\end{array}$ & $\%$ & $\begin{array}{l}\text { Female } \\
\text { No. }\end{array}$ & $\%$ \\
\hline \multirow[t]{2}{*}{ SURFACE } & $\begin{array}{l}\text { SI: No evidence of sharing of } \\
\text { ideas or group discussion }\end{array}$ & 22 & $26 \%$ & 12 & $24 \%$ & 10 & $29 \%$ \\
\hline & $\begin{array}{l}\text { S2: Sharing of ideas about } \\
\text { assignment without discussion } \\
\text { of underlying subject matter }\end{array}$ & 14 & $17 \%$ & 6 & $12 \%$ & 8 & $24 \%$ \\
\hline \multicolumn{2}{|c|}{ Total: Surface Approach } & 36 & $43 \%$ & 18 & $36 \%$ & 18 & $53 \%$ \\
\hline DEEP & $\begin{array}{l}\text { DI: Group discussion of } \\
\text { underlying concepts; individual } \\
\text { members deepen understanding }\end{array}$ & 8 & $10 \%$ & 5 & $10 \%$ & 3 & $9 \%$ \\
\hline
\end{tabular}

(Continued) 
TABLE 4: (CONTINUED)

\begin{tabular}{lcccccc}
\hline $\begin{array}{c}\text { Learning } \\
\text { Approach }\end{array}$ & Group Work Process & $\begin{array}{c}\text { Total } \\
\text { No. }\end{array}$ & $\begin{array}{c}\text { Male } \\
\text { No. }\end{array}$ & $\begin{array}{c}\text { Female } \\
\text { No. }\end{array}$ & $\%$ \\
\hline $\begin{array}{l}\text { D2: Group as a whole achieves } \\
\text { higher understanding }\end{array}$ & 23 & $27 \%$ & 16 & $32 \%$ & 7 & $20 \%$ \\
Total: Deep Approach & 31 & $37 \%$ & 21 & $42 \%$ & 10 & $29 \%$ \\
Inconsistent Responses & 17 & $20 \%$ & 11 & $22 \%$ & 6 & $18 \%$ \\
TOTAL & 84 & $100 \%$ & 50 & $100 \%$ & 34 & $100 \%$ \\
\hline
\end{tabular}

TABLE 5: GROUP WORK APPROACHES, ASSOCIATED WITH RE-CATEGORISED APPROACHESTO LEARNING

\begin{tabular}{|c|c|c|c|c|c|c|c|}
\hline $\begin{array}{l}\text { Learning } \\
\text { Approach }\end{array}$ & Group Work Process & $\begin{array}{l}\text { Total } \\
\text { No. }\end{array}$ & $\%$ & $\begin{array}{l}\text { Male } \\
\text { No. }\end{array}$ & $\%$ & $\begin{array}{c}\text { Female } \\
\text { No. }\end{array}$ & $\%$ \\
\hline SURFACE & $\begin{array}{l}\text { SI: No evidence of sharing of } \\
\text { ideas or group discussion }\end{array}$ & 22 & $26 \%$ & 12 & $24 \%$ & 10 & $29 \%$ \\
\hline STRATEGIC & $\begin{array}{l}\text { SA: Group discussion of } \\
\text { underlying concepts/Sharing of } \\
\text { ideas about assignment }\end{array}$ & 22 & $26 \%$ & II & $22 \%$ & II & $33 \%$ \\
\hline DEEP & $\begin{array}{l}\text { D2: Group as a whole achieves } \\
\text { higher understanding }\end{array}$ & 23 & $27 \%$ & 16 & $32 \%$ & 7 & $20 \%$ \\
\hline \multicolumn{2}{|c|}{ Inconsistent Responses } & 17 & $20 \%$ & II & $22 \%$ & 6 & $18 \%$ \\
\hline \multicolumn{2}{|l|}{ TOTAL } & 84 & $100 \%$ & 50 & $100 \%$ & 34 & $100 \%$ \\
\hline
\end{tabular}

In total, 26 per cent of students indicated that the work was simply subdivided with no subsequent refinement at a group level (surface learning approach). For these students, each individual did one part of any group assignment, but there was no group discussion and refinement of the ideas or of the individual sections comprising that assignment. The individual sections of group tasks were not discussed or refined by the entire group. Ideas on individual sections were not shared across the group. For example, one student described group work processes as representing 'time taken away from other projects' [Student A28]. For another, working in groups '... enables you to split work load ... ensures accuracy ... 3 or 4 people are checking assignments instead of one' [Student F10]. The student focus here is very much on maximising individual utility, whilst minimising cost, in an almost instrumental manner:

The best aspect is that employers like to see that you have worked in groups and see it as beneficial. The worst is that group projects take up more time than they are worth. If it was a $20 \%$ exam or assignment, it would take less time ... Perhaps group work should be done from $1^{\text {st }}$ to $3^{\text {rd }}$ year [Student A15].

Group work processes compromise individual efforts: '... your overall work can be compromised; can't work at your own pace' [Student F33]. 
Healy et al.

A further 26 per cent (strategic learning approach) went so far as to moderate ideas and content, but did not discuss the underlying concepts of those assignments or tasks as a group. For these students, the group is used to share the workload as it is the most expedient way of tackling group tasks. The group is also used to moderate ideas and content, towards producing acceptable academic assignments and eliminating anything that might not be relevant or appropriate to the required group output. For example, one student described group work processes as positive in terms of ' ... getting other members' feedback/thoughts on issues, assigning work based on strengths; learning from other members', but also recognised the following:

Some individuals take over, so you don't have a chance to learn about the subject. Delegation of work within [the] group can result in you not experiencing/learning from all aspects of assignments. [Student A38].

For some of these students, the group work process is seen as helping individuals learn by providing additional good ideas which enhance individual learning. Students discussed underlying concepts and gained individual understanding. One student described group work as offering '... the ability to discuss and solve problems that if in an individual project would require the lecturer's help' [Student F24].

Finally, 27 per cent of students report a process whereby the group as a whole gains a higher level of understanding both of the assignment content or group work task and also of the subject area(s) more generally, rather than just the course content around the specific group work assignment (deep learning approach). In summing up the positive aspects of group work processes, students in this grouping report a range of benefits:

You can learn a lot from your other group members. You can split the workload. If you do not understand some part, you can talk about it with your group and understand it better. Everyone brings different strengths to the group. [Student F18].

I think working in groups allows students to get a good understanding of harder topics when they put their heads together. It is good that different people bring different things to the group. It helps communication skills and presentations. It is good when all members want to do the same level of work. [Student A32].

Getting to know people, finding your strengths, learning from each other, better ideas generated, valuable skills for employment. [Student A36].

However, the same student also stated free-riders could be an issue and that there are '... too many ideas at times, hard [to] agree on one goal' [Student A36].

Table 6 reports overall responses to the value of group work questions (mean and standard deviation), for the respondents in each of the learning approaches (deep, strategic and surface) represented in Table 5. Statements in the first column are listed in the order of mean score (from highest to lowest). Differences in responses were tested using Kruskal-Wallis tests. The mean scores reported in Table 6 suggest that for these respondents group work was in general a positive experience, 
notwithstanding their views regarding the level of guidance provided on effective team working (mean score of 2.71). For the students as a whole the greatest value was placed on skills for employers, but also the social aspects of group work, i.e. learning from other students and getting to know other students. The least positive responses related to the level of preparation received. Consistently, those who described taking a deeper approach to learning reported more positively on the value of group work. Having established statistically significant differences based on approach to learning, Mann-Whitney $U$ tests were used to explore these differences further. Table 7 reports the findings of this analysis.

TABLE 6:VALUE OF GROUP WORK

\begin{tabular}{|c|c|c|c|c|}
\hline & \multicolumn{2}{|c|}{ APPROACH TO LEARNING } \\
\hline $\begin{array}{c}\text { Value of group work } \\
\text { (Scale: 5 = Strongly Agree; I = Strongly Disagree) }\end{array}$ & $\begin{array}{c}\text { All } \\
\text { Mean } \\
(\text { SD })\end{array}$ & DEEP & STRATEGIC & SURFACE \\
\hline $\begin{array}{c}\text { Group work provides a skill which is valued by } \\
\text { employers }\end{array}$ & $\begin{array}{c}4.52 \\
(0.53)\end{array}$ & 4.57 & 4.50 & 4.50 \\
\hline $\begin{array}{c}\text { Group work helped me to get to know the } \\
\text { other students }\end{array}$ & $\begin{array}{c}4.23 \\
(0.68)\end{array}$ & 4.39 & 4.10 & 4.18 \\
\hline $\begin{array}{c}\text { Group work enabled me to learn from other } \\
\text { students }\end{array}$ & $\begin{array}{c}4.03 \\
(0.78)\end{array}$ & $4.35^{* *}$ & $3.82^{* *}$ & $3.9 I^{* *}$ \\
\hline $\begin{array}{c}\text { The group assignments taught me how to } \\
\text { work effectively in a team }\end{array}$ & $\begin{array}{c}3.94 \\
(0.67)\end{array}$ & 4.04 & 3.95 & 3.82 \\
\hline $\begin{array}{c}\text { I learn more about the subject area from } \\
\text { individual assignments than from group work }\end{array}$ & $\begin{array}{c}3.76 \\
(0.99)\end{array}$ & $3.45^{*}$ & $3.73^{*}$ & $4.09^{*}$ \\
\hline $\begin{array}{c}\text { Group work helped me to learn more about } \\
\text { the subject area }\end{array}$ & $\begin{array}{c}3.69 \\
(0.86)\end{array}$ & $4.00^{*}$ & $3.4 I^{*}$ & $3.64^{*}$ \\
\hline $\begin{array}{c}\text { The same people always took the lead in } \\
\text { group work }\end{array}$ & $\begin{array}{c}3.67 \\
(0.84)\end{array}$ & 3.65 & 3.59 & 3.77 \\
\hline $\begin{array}{c}\text { The group assessments were of a higher } \\
\text { quality than if we had done them individually }\end{array}$ & $\begin{array}{c}3.43 \\
(0.91)\end{array}$ & 3.65 & 3.18 & 3.45 \\
\hline $\begin{array}{c}\text { I produce better work by working alone than } \\
\text { by working in groups }\end{array}$ & $\begin{array}{c}3.38 \\
(0.92)\end{array}$ & $3.00^{*}$ & $3.59^{*}$ & $3.55^{*}$ \\
\hline $\begin{array}{l}\text { I was given sufficient guidance on how to work } \\
\text { effectively in a group }\end{array}$ & $\begin{array}{c}2.71 \\
(0.87)\end{array}$ & 2.91 & 2.50 & 2.73 \\
\hline
\end{tabular}

$*^{*} p<0.05$ and $*_{p}<0.10$

Table 7 presents pairwise comparisons based on approach to learning, of student views of the value of group work. It is notable that there were no significant differences between the reported views on the value of group work between surface and strategic learners. However, a deep approach to learning was associated in a statistically significant manner both with learning from other students and with learning 
Healy et al.

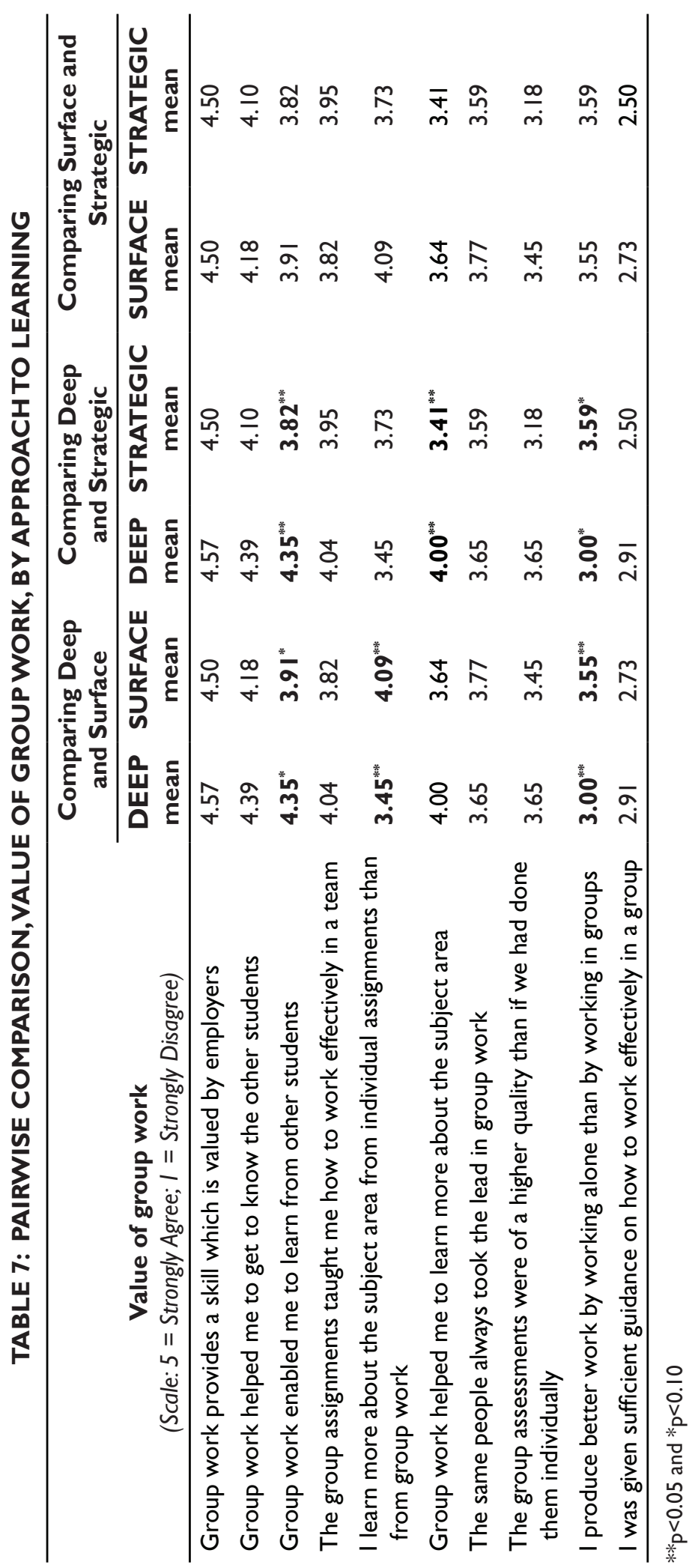


about the subject area through group work. The differences related not to the social aspects of group work but to the learning aspects of group work.

Table 8 reports overall responses to the experience of group work (mean and standard deviation), for the respondents in each of the learning approaches (deep, strategic and surface) represented in Table 5 . The descriptors in the first column are listed in the order in which they were presented in the survey instrument. Differences in responses were tested using Kruskal-Wallis tests.

TABLE 8: EXPERIENCE OF GROUP WORK

\begin{tabular}{|c|c|c|c|c|}
\hline \multirow[b]{2}{*}{$\begin{array}{c}\text { Experience of group work } \\
\text { (Scale: } 5 \text { = Strongly Agree; } I=\text { Strongly } \\
\text { Disagree) }\end{array}$} & \multirow[b]{2}{*}{$\begin{array}{l}\text { All } \\
\text { Mean } \\
\text { (SD) }\end{array}$} & \multicolumn{3}{|c|}{ APPROACH TO LEARNING } \\
\hline & & DEEP & STRATEGIC & SURFACE \\
\hline Enjoyable & $\begin{array}{c}3.45 \\
(1.02)\end{array}$ & $3.78^{*}$ & $3.41^{*}$ & $3.14^{*}$ \\
\hline Stimulating & $\begin{array}{c}3.40 \\
(0.84)\end{array}$ & $3.9 I^{* *}$ & $3.09^{* *}$ & $3.18^{* *}$ \\
\hline Easy & $\begin{array}{c}2.69 \\
(0.91)\end{array}$ & $2.87^{*}$ & $2.36^{*}$ & $2.82^{*}$ \\
\hline Satisfying & $\begin{array}{c}3.00 \\
(1.03)\end{array}$ & $3.48^{* *}$ & $2.64^{* *}$ & $2.86^{* *}$ \\
\hline Beneficial & $\begin{array}{c}3.85 \\
(0.78)\end{array}$ & $4.30^{* *}$ & $3.50^{* *}$ & $3.73^{* *}$ \\
\hline A good learning experience & $\begin{array}{c}3.91 \\
(0.81)\end{array}$ & $4.26^{* *}$ & $3.59^{* *}$ & $3.86^{* *}$ \\
\hline Very creative & $\begin{array}{c}3.15 \\
(0.93)\end{array}$ & $3.48^{* *}$ & $2.68^{* *}$ & $3.27^{* *}$ \\
\hline
\end{tabular}

$*^{*} *_{p}<0.05$ and $*_{p}<0.10$

Based on the mean scores reported in Table 8, whilst not easy (mean of 2.69) or overly satisfying (mean of 3.00), there is perceived value in the group work experience. When compared across approaches to learning, the difference in means does seem contrary to researcher expectations. The researchers would have expected the means for strategic learners to be closer to the means for deep learners, than to those for surface learners. It appears from these scores that the strategic learners have the least positive experience - perhaps explained by the predominant focus of strategic learners on grades (Ramsden, 1979). Having established statistically significant differences based on approach to learning, Mann-Whitney U tests were used to explore these differences further. Table 9 reports the findings of this analysis.

Table 9 illustrates deep learners report more enjoyment, more stimulation, more satisfaction, and overall perceive group work as a beneficial and good learning experience. In this, their experience is significantly more positive than both surface and strategic learners. In comparing surface and strategic learners, significant differences emerge which reflect a general trend apparent in other tables in that 
Healy et al.

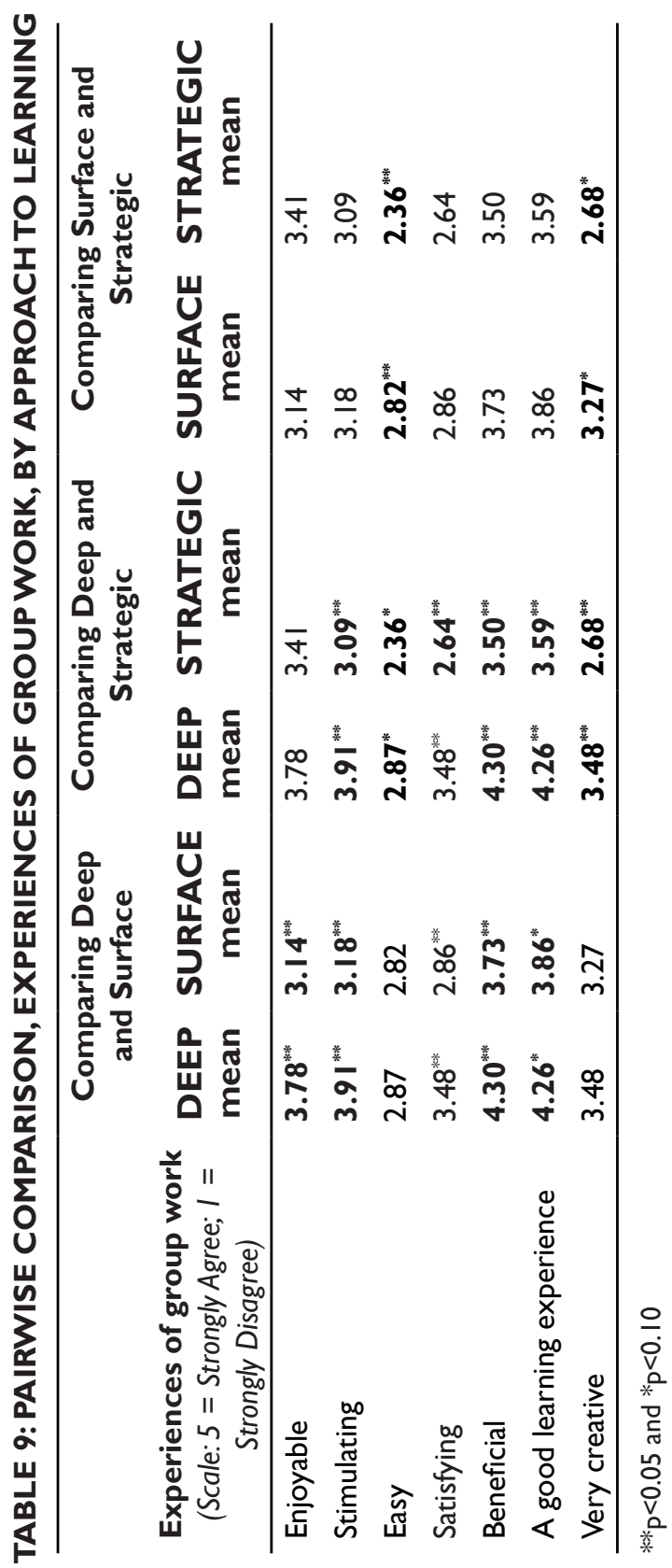


strategic learners have statistically significantly more difficulty with group work and see it as less creative.

\section{DISCUSSION AND CONCLUSIONS}

The research objective of this study is to explore the relationship between accounting students' perceptions of group work experiences and approaches to learning. Using a framework developed by Tempone and Martin (1999), and subsequently adapted to allow for a strategic or achieving approach, three distinct approaches to learning are identified with students divided evenly between them. In this study, unlike that of Cadiz Dyball et al. (2010), only a minority of students (27 per cent) indicated a deep approach to learning.

The findings of this study demonstrate that approach to learning did have a relationship to the perceived value subsequently attached to group work (Table 6) and on the ultimate experience of group work (Table 8). A deep approach to learning is associated with a significantly higher value being placed by students on some aspects of the experience of working in groups. They placed a higher value both on the peer learning aspects and on the subject learning. These differences were significant between deep and surface learners and between deep and strategic learners (Table 7). There were no significant differences between strategic and surface learners in the value they attached to group work, although strategic learners reported lower mean values. By contrast, the findings demonstrate that those who adopted a surface or a strategic approach were more likely to perceive that they do better work and learn more by working alone rather than in groups (Table 6). However, the direction of causality is not clear.

This study is based on the cumulative experience of working in groups and, as already identified in the literature, group work can be motivated by a skills agenda where the objective is to enhance employability rather than by a desire to encourage deeper learning. This study identifies an association between deeper learning and engagement with group work, but it is unclear whether the pedagogic approach encourages deeper learning or deeper learning encourages engagement with the pedagogic approach. Approaches to learning are not fixed characteristics and the nature of tasks and the assessment of tasks can be important presage factors for the group work process adopted by students.

The value of group work in part reflects experiences of the group work process: group work is known to be challenging with the literature replete with accounts of free-rider issues, storming behaviours and a lack of clear direction. In this study, students were asked to rate their experience of group work across a number of descriptors and in all cases those students who reflected a deeper approach to learning had a significantly more positive experience and were apparently more engaged in the process (Table 8). It is interesting that the experience of the strategic learners tended to be the least positive of the three groups and in the case of two dimensions - 'Easy' and 'Very creative' - the strategic learners perceived the experience to be significantly more problematic than did the surface learners (Table 9). 
Healy et al.

The approaches to learning in groups documented in this study reflect different processes adopted by students in how they go about dividing up the work and discussing and reflecting on the tasks. At one extreme, surface learners simply split up the work and do not attempt any meaningful collaboration. At the other extreme, deeper learners in a group work context aim to learn more about the subject area beyond the confines of the assignment itself; they are fully engaged in that their motives and strategy are aligned. It is possible for some deep learners to find the challenges of group working to be such that they do not adopt deep learning strategies in the group learning context.

In between these extremes are the strategic learners who may be reluctant group workers. They adopt a strategy of group working of sharing ideas and collaborating - but this is not necessarily from a motivation to learn from each other but from a concern to complete the assignment and secure the best grades. This suggests that strategic learners may be experiencing a form of dissonance, as referenced by Lucas and Mladenovic (2004), in that their motives are not in line with their strategy. They are reluctant group workers. While the surface learners circumvent the demands of the task and the deep learners embrace it, the strategic learners are attempting to complete the task without an underlying belief in its value or relevance. This negatively impacts both on the value they gain from the task and on their engagement with it.

A unique contribution of this study is that it examines students' perceptions of their cumulative experience of group work. It was therefore not possible to consider specific aspects such as group formation and free-rider issues which may have influenced some of those experiences but not others. Future research could address specific group work processes in this regard. The link between group work experience and employability is also an area which needs to be further addressed in the specific context of accounting students. For example, this could usefully be investigated in a study which relates students' approach to group work to their experiences on work placement. A potential related further study could compare lecturers' opinions on the student learning experience to students' own perceptions, and the effect of this on the design and conduct of group assessment.

In sum, for students to engage with group work in a manner which brings benefits in terms of deeper learning as well as enhanced employability requires lecturers to first address the need to align the learning process to the desired learning outcomes. Higher quality learning will only result if higher quality learning is inspired by the learning task. It is also necessary to recognise that those students who identify as strategic learners (as Irish accounting students tend to be: Byrne et al., 2002; Healy and McCutcheon, 2008) may well embrace the letter but not the spirit of the task. For change to occur in their approach to learning, it is necessary to engage in dialogue which addresses their motivations and apprehensions, and jointly constructs learning activities perceived as relevant. This is unlikely to be achievable on a single module basis as it pertains to students' views on what is relevant in accounting education as a whole and emphasises the need to have a coordinated programme-wide view to challenge the student traditional view of accounting education. 
APPENDIX 1

\begin{tabular}{|c|c|c|}
\hline $\begin{array}{l}\text { Tempone and } \\
\text { Martin (1999) } \\
\text { Outcome Space }\end{array}$ & Group Process (Table 3 ) & $\begin{array}{c}\text { Categorisations Based on } \\
\text { the Research Findings of This } \\
\text { Study }\end{array}$ \\
\hline A & No group work & Not relevant to this study \\
\hline B & $\begin{array}{l}\text { No evidence of sharing of ideas or } \\
\text { group discussion }\end{array}$ & $\begin{array}{l}\text { Agreed with statement I, but not } \\
\text { with statements } 2 \text { and } 3\end{array}$ \\
\hline C & $\begin{array}{l}\text { Sharing of ideas about assignment } \\
\text { without discussion of underlying } \\
\text { subject matter }\end{array}$ & $\begin{array}{l}\text { Agreed with statements } 2 \text { and } 3 \text {, } \\
\text { but did not agree with statements } \\
4 \text { and } 5\end{array}$ \\
\hline $\mathrm{D}, \mathrm{E}$ & $\begin{array}{l}\text { Group discussion of underlying } \\
\text { concepts; individual members deepen } \\
\text { understanding }\end{array}$ & $\begin{array}{l}\text { Agreed with statements } 2,3 \text { and } 4 \text {, } \\
\text { but not with statement } 5\end{array}$ \\
\hline $\mathrm{F}$ & $\begin{array}{l}\text { Group as a whole achieves higher } \\
\text { understanding }\end{array}$ & $\begin{array}{l}\text { Agreed with statements } 2,3,4 \text { and } \\
5\end{array}$ \\
\hline
\end{tabular}

\section{REFERENCES}

Accounting Education Change Commission (AECC) (1990). Objectives of Education for Accountants: Position Statement Number One, Issues in Accounting Education, Vol. 5, No. 2, pp. 307-312.

Albrecht, W. and Sack, R. (2000). Accounting Education: Charting the Course through a Perilous Future, Accounting Education Series (16), Sarasota, FL:American Accounting Association.

Ballantine, J. and McCourt Larres, P. (2007). Final Year Accounting Undergraduates' Attitudes to Group Assessment and the Role of Learning Logs, Accounting Education, Vol. 16, No. 2, pp. 163-183.

Biggs, J. and Tang, C. (2003). Teaching for Quality Learning at University, Maidenhead: Society for Research into Higher Education and Open University Press.

Bourner, J., Hughes, M. and Bourner, T. (2001). First-Year Undergraduate Experiences of Group Project Work, Assessment E Evaluation in Higher Education, Vol. 26, No. 1, pp. 19-39.

Brown, R. and McCartney, S. (1995). Competence Is Not Enough: Meta-Competence and Accounting Education, Accounting Education, Vol. 4, No. 1, pp. 43-53.

Bui, B. and Porter, B. (2010). The Expectation-Performance Gap in Accounting Education: An Exploratory Study, Accounting Education, Vol. 19, No. 1-2, pp. 23-50.

Bunniss, S. (2006). Purpose and Gift; Resisting Vocational Capture in Accounting Education: The Story from One Scottish University, unpublished doctoral thesis, University of Strathclyde.

Byrne, M. and Flood, B. (2004). Exploring the Conceptions of Learning of Accounting Students, Accounting Education, Vol. 13, Supplement 1, pp. 25-37.

Byrne, M., Flood, B. and Willis, P. (2002). The Relationship between Learning Approaches and Learning Outcomes: A Study of Irish Accounting Students, Accounting Education, Vol. 11, No. 1, pp. 27-42.

Cadiz Dyball, M., Reid, A., Ross, P. and Schoch, H. (2010). Compulsory Group Work Accounting Students' Conceptions and Suggestions, Asian Review of Accounting, Vol. 18, No. 2, pp. 92-105. 
Healy et al.

Chabrak, N. and Craig, R. (2013). Student Imaginings, Cognitive Dissonance and Critical Thinking, Critical Perspectives on Accounting, Vol. 24, No. 2, pp. 91-104.

Davies, W. (2009). Groupwork as a Form of Assessment: Common Problems and Recommended Solutions, Higher Education, Vol. 58, No. 4, pp. 563-587.

Duff, A. (2004). Understanding Academic Performance and Progression of First-Year Accounting and Business Economics Undergraduates: The Role of Approaches to Learning and Prior Academic Achievement, Accounting Education, Vol. 13, No. 4, pp. 409-430.

Evans, E., Burritt, R. and Guthrie, J. (editors) (2012). Emerging Pathways for the Next Generation of Accountants, The Institute of Chartered Accountants in Australia \& Centre for Accounting, Governance and Sustainability, University of South Australia.

Gammie, E. and Matson, M. (2007). Group Assessment at Final Degree Level: An Evaluation, Accounting Education, Vol. 16, No. 2, pp. 185-206.

Healy, M., Doran, M. and McCutcheon, M. (2018). Cooperative Learning Outcomes from Cumulative Experiences of Group Work: Differences in Student Perceptions, Accounting Education, Vol. 27, No. 3, pp. 286-308.

Healy, M. and McCutcheon, M. (2008). Engagement with Active Learning: Reflections on the Experiences of Irish Accounting Students, Irish Accounting Review, Vol. 15, No. 1, pp. 31-49.

Hillyard, C., Gillespie, D. and Littig, P. (2010). University Students' Attitudes about Learning in Small Groups after Frequent Participation, Active Learning in Higher Education, Vol. 11, No. 1, pp. 9-20.

Hopper, T. (2013). Making Accounting Degrees Fit for a University, Critical Perspectives on Accounting, Vol. 24, No. 2, pp. 127-135.

Johnson, D. and Johnson, R. (1999). Making Cooperative Learning Work, Theory into Practice, Vol. 38, No. 2, pp. 67-73.

Kember, K. and Gow, L. (1994). Orientations to Teaching and Their Effect on the Quality of Student Learning, The Journal of Higher Education, Vol. 65, No. 1, pp. 58-74.

Lucas, U. and Mladenovic, R. (2004). Approaches to Learning in Accounting Education, Accounting Education, Vol. 13, No. 4, pp. 399-407.

Marton, F. and Booth, S. (1997). Learning and Awareness, Mahwah, NJ: Lawrence Erlbaum.

Marton, F. and Säljö, R. (1976). On Qualitative Differences in Learning. I. Outcome and Process, British Journal of Educational Psychology, Vol. 46, pp. 4-11.

Marton, F. and Säljö, R. (1984). Approaches to learning in Marton, F., Hounsell, D. and Entwistle, N. (eds.) The Experience of Learning, Edinburgh: Scottish Academic Press.

Merino, B. (2006). Financial Scandals: Another Clarion Call for Educational Reform - A Historical Perspective, Issues in Accounting Education, Vol. 21, No. 4, pp. 363-381.

Mills, P. (2003). Group Project Work with Undergraduate Veterinary Science Students, Assessment $\mathcal{E}$ Evaluation in Higher Education, Vol. 28, No. 5, pp. 527-538.

Norman, C., Rose, A. and Lehmann, C. (2004). Cooperative Learning: Resources from the Business Disciplines, Journal of Accounting Education, Vol. 22, No. 1, pp. 1-28.

Paisey, C. and Paisey, N. (2000). A Comparative Study of Undergraduate and Professional Education in the Professions of Accountancy, Medicine, Law and Architecture, Edinburgh: The Institute of Chartered Accountants of Scotland.

Pauli, R., Mohiyeddini, C., Bray, D., Michie, F. and Street, B. (2008). Individual Differences in Negative Group Work Experiences in Collaborative Student Learning, Educational Psychology: An International Journal of Experimental Educational Psychology, Vol. 28, No. 1, pp. 47-58.

Previts, G. and Merino, B. (1997). History of Accountancy in the United States: The Cultural Significance of Accounting, Columbus, OH: Ohio State University Press. 
Quality and Qualifications Ireland (QQI) (2014). Awards Standards - Business, Quality and Qualifications Ireland, available from: www.qqi.ie/Publications/Publications/Business\%20-\%20Awards\%20Standards.pdf last accessed 13 December 2018.

Ramsden, P. (1979). Student Learning and Perceptions of the Academic Environment, Higher Education, Vol. 8, No. 4, pp. 411-427.

Ramsden, P. (2003). Learning to Teach in Higher Education, second edition, London and New York, NY: Routledge Farmer.

Ravenscroft, S. (1997). In Support of Cooperative Learning, Issues in Accounting Education, Vol. 12, No. 1, pp. 187-190.

Roslender, R. (2002). Sociological Perspectives on Modern Accountancy, London and New York, NY: Routledge.

Schultz, J. (1989). Reorienting Accounting Education, Sarasota, FL: American Accounting Association.

Tempone, I. and Martin, E. (1999). Accounting Students' Approaches to Group-Work, Accounting Education, Vol. 8, No. 3, pp. 177-186.

Wilson, R. (2011). Alignment in Accounting Education and Training, Accounting Education, Vol. 20, No. 1, pp. 3-16.

Wyatt, A. (2004). Accounting Professionalism - They Just Don't Get It! Accounting Horizons, Vol. 18, No. 1, pp. 45-53.

Wyhe, G. (2007). A History of US Higher Education in Accounting, Part I: Situating Accounting within the Academy, Issues in Accounting Education, Vol. 22, No. 2, pp. 163-181. 